\title{
ENVIRONMENTAL TECHNOLOGIES
}

DOI https://doi.org/10.30525/978-9934-26-046-9-42

\section{ВИДАЛЕННЯ СО 3 ГАЗІВ ЗА ДОПОМОГОЮ КАТАЛІЗАТОРІВ НА ОСНОВІ ФЕРИТНИХ МАТЕРІАЛІВ}

\author{
Довголап С. Д. \\ аспірант \\ Національний технічний університет України \\ «Київський політехнічний інститут імені Ігоря Сікорського»
}

Іваненко О. I.

кандидат технічних наук, дочент

Національний технічний університет Украйни

«Київський політехнічний інститут імені Ігоря Сікорського»

м. Київ, Україна

В технологічних процесах, де зустрічається термічна обробка вуглецю, таких як коксування, графітація, спалювання вугілля, завжди утворюються оксиди вуглецю, якщо в газових сумішах присутній в більших чи менших концентраціях кисень. Як правило, дані процеси супроводжуються утворенням діоксиду вуглецю та токсичного монооксиду вуглецю[1, с. 9-16].

Не дивлячись на значну кількість методів доокислення монооксиду вуглецю перед скидом димових газів у атмосферу, задача створення умов ефективного його окислення на стадії отримання $\epsilon$ важливою проблемою, яка недостатньо вивчена.

Одним із конструктивних рішеннь проблеми очистки димових газів багатокамерних печей [2] для випалювання електродних заготовок від монооксиду вуглецю може бути розміщення у вогневих каналах цих печей контейнерів 3 каталізатором у камерах, що підігріваються димовими газами. Таким чином, метою роботи $є$ розробка каталізаторів окислення СО для вирішення важливої наукової і прикладної проблеми техногенного забруднення навколишнього середовища підприємствами з виробництва електродів. 
В ходів даних досліджень були проведені лабораторні експерименти 3 наступними каталізаторами на основі феритних матеріалів.

Мідь-феритовий каталізатор $(\mathrm{Cu} 2+: \mathrm{Fe} 2+=1: 3,53)$ на основі цеоліту [2]: наважку цеоліту обробляли сумішшю розчинів $0,069 \mathrm{M} \mathrm{CuSO} 4$ та 0,278M FeSO4 протягом 1 год, після чого осаджували на цеоліті осад фериту міді $\mathrm{CuFe}(\mathrm{FeO} 2) 325 \%$ розчином $\mathrm{NH} 4 \mathrm{OH}$ за реакцією:

$2 \mathrm{Cu} 2++8 \mathrm{Fe} 2++20 \mathrm{NH} 4 \mathrm{OH}+\mathrm{O} 2 \rightarrow 2 \mathrm{CuFe}(\mathrm{FeO} 2) 3 \downarrow+10 \mathrm{H} 2 \mathrm{O}+$ 20NH4+ та витримували протягом 24 год. Після цього модифікований цеоліт відділяли від водної фази декантацією, промивали та сушили на повітрі до постійної маси.

Хром-феритовий каталізатор ( $\mathrm{Cr} 6+: \mathrm{Fe} 2+=1: 15)$ на основі цеоліту [3, с. 215]: наважку цеоліту обробляли сумішшю розчинів $0,028 \mathrm{M}$ $\mathrm{K} 2 \mathrm{Cr} 2 \mathrm{O} 7$ та 0,332M FeSO4 протягом 1 год, після чого осаджували на цеоліті осад фериту хрому $25 \%$ розчином $\mathrm{NH} 4 \mathrm{OH}$ за реакціями:

$\mathrm{Cr} 2 \mathrm{O} 72-+2 \mathrm{OH}-\rightarrow 2 \mathrm{CrO} 42-+\mathrm{H} 2 \mathrm{O}$,

$2 \mathrm{~K} 2 \mathrm{CrO} 4+9 \mathrm{Fe}(\mathrm{OH}) 2 \rightarrow 3 \mathrm{Fe} 3 \mathrm{O} 4 \downarrow+2 \mathrm{Cr}(\mathrm{OH}) 3 \downarrow+4 \mathrm{KOH}+4 \mathrm{H} 2 \mathrm{O}$

та витримували протягом 24 год. Після цього модифікований цеоліт відділяли від водної фази декантацією, промивали та сушили на повітрі до постійної маси.

Феритовий каталізатор $(\mathrm{Fe} 2+: \mathrm{Fe} 3+=1: 2)$ на основі цеоліту [3, с. 215]: наважку цеоліту обробляли сумішшю розчинів $0,119 \mathrm{M}$ $\mathrm{FeSO} 4$ та 0,238M FeCl3 протягом 1 год, після чого осаджували на цеоліті осад магнетиту $\mathrm{Fe} 3 \mathrm{O} 425 \%$ розчином $\mathrm{NH} 4 \mathrm{OH}$ та витримували протягом 24 год, реакція отримання даного каталізатора:

$\mathrm{FeSO} 4+2 \mathrm{FeCl} 3+8 \mathrm{NH} 4 \mathrm{OH} \rightarrow \mathrm{Fe} 3 \mathrm{O} 4 \downarrow+4 \mathrm{H} 2 \mathrm{O}+(\mathrm{NH} 4) 2 \mathrm{SO} 4+$ $6 \mathrm{NH} 4 \mathrm{Cl}$

Дослідження процесу окислення СО в створеній установці: установка (рис. 1) включає термокамеру 8, що складається 3 металевої трубки з нержавіючої сталі 9 та керамічної трубки 10 з нагрівальним елементом 11 в якій за допомогою термопар 12 та термореле 13 підтримується за допомогою елемента 11 задана температура. Зразок каталізатору з розміром зерна 3-5-8 мм в циліндричному контейнері 13 поміщали в металеву трубку 9. Розміри контейнеру складали: висота 160 мм, діаметр 60 мм. Контейнер з каталізатором висотою 50 мм вставляли в трубку 9 таким чином, щоб виключити проходження газової суміші повз каталізатор. 


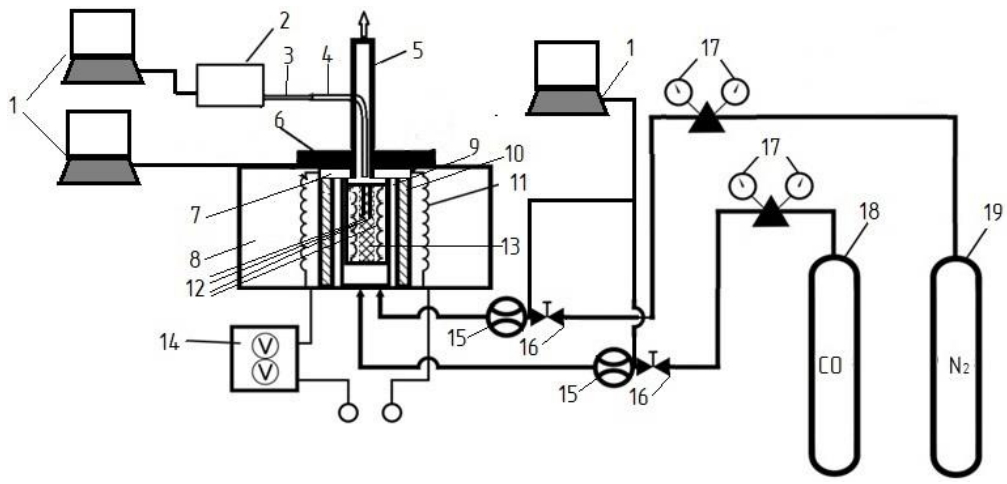

Рис. 1. Схема лабораторної установки для вивчення процесів каталітичного окислення монооксиду вуглецю:

1 - иифровий інтерфейс вимірювань; 2 - газоаналізатор VARIO PLUS industrial analyzer MRU air fair; 3 - газовідбірник газоаналізатора; 4 - трубка для відбору газової суміші з камери в газоаналізатор; 5 - відведення газової суміші; 6-металева прокладка; 7 - азбестова прокладка; 8 - термокамера; 9 - трубка із нержавіючої сталі; 10 - керамічна трубка; 11 - нагрівальний елемент; 12 - термопари; 13 - контейнер для каталізатора із сітки з нержавіючої сталі; 14 - регулятор температури; 15 - газові витратоміри Bronkhorst EL-FLOW F-111AC; 16 - регулюючі клапани F-001AC; 17 - редуктори; 18 - балон із монооксидом вуглеию; 19 - балон із азотом

Об'ємну швидкість газового потоку варіювали в інтервалі 1-5 дм3/хв. У процесі нагрівання постійно контролювали склад газової суміші на вході та виході з термокамери. За необхідності в якості інертного газу використовували азот. Концентрацію продуктів реакції аналізували за допомогою газоаналізатора VARIO PLUS industrial analyzer MRU air fair, 3 точністю \pm 20 ppm або $\pm 5 \%$ значень вимірювання. Безпосередньо перед проведенням каталітичного експерименту зерно каталізатору піддавали термообробці за температури $450{ }^{\circ} \mathrm{C}$ на протязі 2 год. Перед та після нагрівання і охолодження визначали втрату маси каталізатора. Каталітичну очистку газової суміші від CO досліджували в інтервалі $200-400{ }^{\circ} \mathrm{C}$.

В результаті проведених досліджень було встановлено що максимальна ступінь окислення СО з використанням всіх типів каталізаторів досягалася при температурі 390 0С. Найефективнішим каталізатором виявся хром-феритний каталізатор при його використанні конверсія СО при температурі 390 0С складала 82,4 Конверсія СО при температурі 390 0С при використанні фертиного та мідь- феритного каталізатора склала $48,5 \%$ та $41,2 \%$. 
Слід зазначити, що мідь феритний каталізатор , найменш ефективний при температурах нижче $3500 \mathrm{C}$, а кращі показники конверсії СO хром-феритного каталізатора спостерігалася з початкової температури 200 0С, ефективність даного каталізатора дорівнювала 49\% , що вища ніж ефективність двох інших каталізаторів, при максимальній температурі випробувань.

В результаті досліджень було визначено, що каталізатори на основі феритних матеріалів, є ефективним для конверсії $\mathrm{CO}$ з газів та підтверджує актуальність даного дослідження. Дані каталізатори можливо успішно застосовувати для очищення газів на промислових підприємствах.

\title{
Література:
}

1. Курсов С. В. Монооксид углерода: физиологическое значение и токсикология // Медицина неотложных состояний. 2015. 6(69). C. 9-16.

2. Riedhammer. 2006. Ring Pit Furnaces for Baking of high quality Anodes - an Overview, 15. URL: http://www.riedhammer.de/system/ 00/01/42/14219/633776329561250000_1.pdf

3. Радовенчик В. М., Іваненко О. І., Радовенчик Я. В., Крисенко Т. В. Застосування феритних матеріалів в процесах очищення води / Монографія. - Біла Церква: Видавництво О. В. Пшонківський, 2020. - 215 c. ISBN 978-617-604-065-2

DOI https://doi.org/10.30525/978-9934-26-046-9-43

\section{ВДОСКОНАЛЕННЯ ТЕХНОЛОГІЧНОЇ СХЕМИ ОЧИСТКИ ШАХТНИХ ВОД НА ОСНОВІ ЇХНЬОГО ДООЧИЩЕННЯ В ШВИДКИХ ЗЕРНИСТИХ ФІЛЬТРАХ}

\author{
Кулікова Д. В. \\ кандидат технічних наук, дочент, \\ доиент кафедри екологї та технологій захисту \\ навколишнього середовища \\ Національний технічний університет "Дніпровська політехніка» \\ м. Дніпро, Украӥна \\ Будь-яка діяльність людини пов'язана з перетворенням довкілля, \\ але найбільш масштабна трансформація природи спричиняється гір- \\ ничими роботами, серед яких у числі перших $\epsilon$ видобуток вугілля.
}

